Int Arch Allergy Appl Immunol 1989;89:I-V

\title{
Contents, Vol. 89, 1989
}

International Archives

Applied

Immunology

Vol. 89, 1989

Founded 1950 by D. Harley, P. Kallós, W. Löffler and F.W. Wittich

Continued by E.A. Brown (1952-1954), W. Kaufman (1955-1967), F. Hahn (1961-1972),

H.C. Goodman (1963-1975), R.R.A. Coombs (1955-1984), Z. Trnka (1972-1987),

P. Kallós (1950-1988)

Editors-in-Chief

Contributing Editors

L.Å. Hanson, Göteborg

C.J. Abeyounis, Buffalo, N.Y.

K.D. Murrell, Beltsville, Md.

K. Kano, Tokyo

N.F. Adkinson, Jr., Baltimore, Md.

P.L. Ogra, Buffalo, N.Y.

F. Milgrom, Buffalo, N.Y.

St. Ahlstedt, Uppsala

F. Ørskov, Copenhagen

K. Rother, Heidelberg

B. Albini, Buffalo, N.Y.

Ö. Ouchterlony, Göteborg

G.B. West, Epsom

G. Andres, Buffalo, N.Y.

Z. Ovary, New York, N.Y.

E.L. Becker, Farmington, Conn.

P. Perlmann, Stockholm

N. Blomqvist, Göteborg

E. Pick, Tel Aviv 
R. Burger, Berlin

M. Plaut, Baltimore, Md.

A. Capron, Lille

R.E. Reisman, Buffalo, N.Y.

A. Cerletti, Basel

G. Riethmüller, München

C.G. Cochrane, La Jolla, Calif.

M. Roitt, London

B. Diamant, Copenhagen

U. Rother, Heidelberg

L. Edebo, Göteborg

R. Rylander, Göteborg

S. Elsayed, Bergen

G. Sandberg, Stockholm

W.P. Faulk, Nice

H.D. Schlumberger, Wuppertal

P.G.H. Gell, Birmingham

A. Sehon, Winnipeg

I. Glazer, Tel Aviv

F. Shakib, Derby

R.A. Good, St. Petersburg, Fla.

O. Strannegård, Göteborg

H. Isliker, Lausanne

O. Tönder, Bergen

S.G.O. Johansson, Stockholm

G. Torrigiani, Geneve

E.A. Kabat, New York, N.Y.

J.L. Turk, London

H. Milgrom, Denver, Colo.

E.R. Unanue, Boston, Mass. 
M. Miyasaka, Basel

B.H. Waksman, New York, N.Y.

W. Müller-Ruchholtz, Kiel

G. Wick, Innsbruck

$\mathrm{m}$

Contents Vol. 89,1989

No. 1

Original Paper

Anti-Allergic Effects of Milrinone and Sulmazole in Isolated

Rat Lungs in Comparison with Theophylline

Post, M.J.; te Biesebeek, J.D.; van Rooij, H.H.; Werner, J.;

Porsius, A.J 1

Comparison of the Anti-Anaphylactic Effects of Milrinone,

Sulmazole and Theophylline in the Rat

Post, M.J.; te Biesebeek, J.D.; Werner, J.; van Rooij, H.H.;

Porsius, A.J 6

Accessory Cell Function of Human Vascular Endothelial Cells

in Pokeweed-Mitogen-Stimulated Immunoglobulin Pro

duction by Peripheral Blood Lymphocytes

Hashimoto, Y.; Nakano, K.; Yoshinoya, S.; Tanimoto, K.;

Miyamoto, $\mathrm{T} 11$

Isolation and Characterization of an Allergen-Rich Fraction

Derived from Cultures of Dermatophagoides pteronyssi-

nus. Preliminary Purification of a Protein

Andersen, A 17

Induction of IgE Synthesis in Anti-IgM-Activated Nonatopic

Human B Cells by Recombinant Interleukin-3

Matsumoto, T.; Clark, S.; Rocklin, R.E 24

Immunity to Ocular and Collagen Antigens in Childhood

Arthritis and Uveitis

Petty, R.E.; Hunt, D.W.C 31

CD 1-Positive Epidermal Langerhans Cells in Skin Reactions to Autologous Peripheral-Blood-

Derived Mononuclear Cells in Leprosy Patients Narayanan, R.B.; Natarajan, M.; Katoch, K.;

Sengupta, U. 38

Histamine Release from Peripheral Blood Leukocytes with Purified Bee Venom Allergens:

Effect of Hyperimmune Beekeeper Plasma Clinton, P.M.; Kemeny, D.M.; Youlten, L.J.F.;

Lessof, M.H. 43

Selective IgG Subclass Antibody Response to Insulin in Dia

betic Patients Receiving Animal Insulin Replacement

Therapy

Siddiqi, M.A.; Wangnoo, S.K 49

Eosinophilia in Mouse Regulated by Multiple Factors follow

ing Repeated Stimulations with Ascaris Eggs into the Peri

toneal Cavity

Kano, S.; Kasuya, S.; Ohtomo, H 54 
Analysis of Differing Patterns of Cross-Reactivity of Honey bee and Yellow Jacket Venom-Specific IgE: Use of Purified Venom Fractions

Wypych, J.I.; Abeyounis, C.J.; Reisman, R.E $\quad 60$

Relationship of Serum Venom-Specific IgE Titers to Clinical

Aspects of Stinging Insect Allergy

Reisman, R.E.; DeMasi, J.M 67

Antigen-Induced Bronchopulmonary Alterations in the

Guinea Pig: A New Model of Passive Sensitization Mediated by Mouse IgE Antibodies

Desquand, S.; Lefort, J.; Liu, F.T.; Mencia-Huerta, J.M.;

Vargaftig, B.B 71

Prevention and Reversal of Aerosol LTD4-Induced Changes in

Guinea Pig Pulmonary Mechanics by Wy-48252, an Orally

Active LTD4/E4 Receptor Antagonist

Hand, J.M.; Auen, M.A.; Chang, J.; Englebach, I.M. ... 78 Maternal Determinants of Neonatal

Immune Response to Ov-

albumin: Effect of Breast Feeding on Development of Anti-

Ovalbumin Antibody in the Neonate

Okamoto, Y.; Freihorst, J.; Ogra, P.L 83

Human IgE Response: Virus-Activated IgE Secretors Are In-

terleukin-2-Dependent Cells

Chan, M.A.; Dosch, H.-M 90

Intestinal Permeability and Antigen Absorption in Rheumatoid Arthritis. Effects of

Acetylsalicylic Acid and Sodium

Chromoglycate

Fagiolo, U.; Paganelli, R.; Ossi, E.; Quinti, I.; Cancian, M.;

D’Offizi, G.P.; Fiocco, U 98

Fc-Epsilon-Receptor-Bearing Lymphocytes in Patients with

Clonorchiasis

Watanabe, N.; Yanagihara, Y.; Joh, K; Hamada, A.; Tomita,

Y.; Kobayashi, A 103

Special Paper: Science and Justice

Immunoprecipitation in Court - The Aftermath

Humphrey, GF 108

No. 2-3

Original Paper

Modulation of Total IgE Levels in Serum of Normal and Athymic Nude BALB/c Mice by T

Cells and Exogenous Antigenic Stimulation

Savelkoul, H.F.J.; van den Akker, T.W.; Soeting, P.W.C.;

van Oudenaren, A.; Benner, R

113

Beta-2-Microglobulin of Rat Major Histocompatibility Com

plex Class I Antigens

Misra, D.N.; Kunz, H.W.; Gill, T.J., III 120

$\mathrm{f}$

S. Karger $\cdot$ Medical and Scientific Publishers 


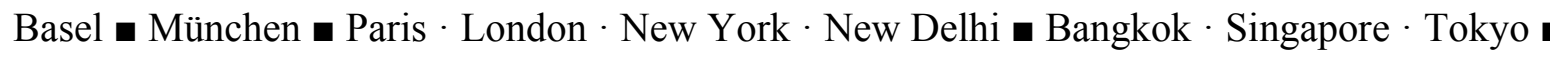
Sydney

Drug Dosage

The authors and the publisher have exerted every effort to ensure that drug selection and dosage set forth in this text are in accord with current recommendations and practice at the time of publication. However, in view of ongoing research, changes in government regulations, and the constant flow of information relating to drug therapy and drug reactions, the reader is urged to check the package insert for each drug for any change in indications and dosage and for added warnings and precautions. This is particularly important when the recommended agent is a new and/or infrequently employed drug.

All rights reserved.

No part of this publication may be translated into other languages, reproduced or utilized in any form or by any means, electronic or mechanical, including photocopying, recording, microcopying, or by any information storage and retrieval system, without permission in writing from the publisher or, in the case of photocopying, direct payment of a specified fee to the Copyright Clearance Center (see 'Information for Readers and Subscribers').

(C) Copyright 1989 by S. Karger AG, P.O. Box, CH-4009 Basel (Switzerland) Printed in Switzerland by Buchdruckerei Basler-Zeitung AG, Basel

Contents

$\mathrm{V}$

Inhibition by Histamine of Platelet-Activating-Factor-Induced

Neutrophil Chemotaxis in Bronchial Asthma

Rabier, M.; Damon, M.; Chanez, P.; Mencia-Huerta, J.-M.;

Braquet, P.; Bousquet, J.; Michel, F.-B.; Godard, P. ... 314 Effect of Reduction and Heat on the Detection of House Dust

Mite (Dermatophagoides pteronyssinus) Allergen Der $\mathrm{p}$ I by

Protein Blotting

Ford, S.A.; Tovey, E.R.; Baldo, B.A 318

No. 4

Original Paper

Characterization of the Proteases in the Crude Mite Extract

Ino, Y.; Ando, T.; Haida, M.; Nakamura, K.; Iwaki, M.;

Okudaira, H.; Miyamoto, T 321

Pigeon Breeder's Disease: The Effect of Antigen-Specific Antibodies on in vitro T Cell

Responses of Normal Blood Lymphocytes Bouic, P.J.; de Beer, P.M.; Daniels, J.; Joubert, J.R. ... 327

An Immunopharmacological Analysis of Adrenaline-Induced

Suppression of Human Natural Killer Cell Cytotoxicity

Hellstrand, K.; Hermodsson, S 334

Allergenic Fragments of Ryegrass (Lolium perenne) Pollen

Allergen Lol p IV

Jaggi, K.S.; Ekramoddoullah, A.K.M.; Kisil, F.T 342

Tetrandrine and Transmembrane Signal Transduction: Effect

on Phosphoinositide Metabolism, Calcium Flux and Pro

tein Kinase C Translocation in Human Lymphocytes 
Ioannoni, B.; Chalmers, A.H.; Seow, W.K.; McCormack,

J.G.; Thong, Y.H 349

Production of Tumor Necrosis Factor/Cachectin by Peripheral Blood Mononuclear Cells in Patients with Systemic Lupus erythematosus Malavé, I.; Searles, R.P.; Montano, L; Williams, R.C., Jr. 355

Actions of the Protease Inhibitor Phenylmethylsulfonyl Fluoride on Neutrophil Granule Enzyme Secretion and Super-oxide Production Induced by fMet-Leu-Phe and Phorbol 12-Myristate-13Acetate

Gomez-Cambronero, J.; Mege, J.-L.; Molski, T.F.P.; Nac-

cache, P.H.; Becker, E.L.; Sha'afi, R.I 362

Human Immune Response against Timothy Grass Pollen Al

lergens. I. Shared Idiotypes on Human and Murine Anti-

gen-B-Specific Lymphocyte Receptors

Malley, A 369

Recombinant Interleukin-1 Triggers the Increase of Circulat

ing Fibronectin Level in Rats (With 1 color plate)

Hagiwara, T.; Kono, I.; Nemoto, K.; Kashiwagi, H.; Ono-

zaki, K 376

In vivo Arming of Cutaneous Mast Cell Receptors by IgE Released from Macrophages Holt, P.G.; Bilyk, N.; Vines, J.; Turner, K.J.; Thomas, W.R. 381

Identification of a Mouse Anti-Rat IgE Monoclonal Antibody, 44.7b, Which Inhibits IgE Binding to RBL Cells

Rup, B.J.; Kahn, L.E 387

In vitro Thymidine Uptake and Incorporation into Thymic

and Bursal Lymphocytes from Young Hypothyroidic

Chickens

Scott, T.R.; Glick, B 394

Experimental Asthma in Guinea Pigs Sensitized with Mites

(Dermatophagoides faunae)

Ishii, A.; Ito, K.; Ino, Y.; Miyamoto, T 400

The Influence of Aluminium on Resistance to Listeria mono-cytogenes in Swiss-Webster Mice

Yoshida, S.; Gershwin, M.E.; Keen, C.L.; Donald, J.M.;

Golub, M.S 404

Synthetic Allergenic Epitopes from the Amino-Terminal Re

gions of the Major Allergens of Hazel and Birch Pollen

Elsayed, S.; Holen, E.; Dybendal, T 410

Short Communication

Establishment of a Chicken x Chicken Hybridoma Secreting

Specific Antibody

Nishinaka, S.; Matsuda, H.; Murata, M 416

Obituary $\quad 420$

Book Reviews 423

Erratum 424

Author Index $\quad 425$

IV

Contents 
Immunogenicity of Three Recombinant Treponema pallidum Antigens Examined in Guinea Pigs Wicher, K.; van Embden, J.D.A.; Schouls, L.M.; Zabek, J.;

Jakubowski, A.; Wicher, V 128

Biological and Immunological Properties of Sugi Basic Pro-

tein-Pullulan Conjugate. I. Suppressive Effect on IgE Anti

body Production and on IgE-Mediated Reactions

Taniguchi, Y.; Ikegami, H.; Usui, ML; Ando, S.; Kurimoto,

M.; Sakaguchi, M.; Inouye, S.; Matuhasi, T 136

Lymphocyte Analysis in a Patient with X-Linked Agamma-globulinemia and Isolated Growth

Hormone Deficiency after Development of Echovirus Dermatomyositis and Me-

ningoencephalitis

Wagner, D.K.; Marti, G.E.; Jaffe, E.S.; Straus, S.E.; Nelson,

D.L.; Fleisher, T.A 143

Acute-Phase Proteins and the Serological Evaluation of Exper

imental Contact Sensitivity in the Mouse

Kimber, I.; Ward, R.K.; Shepherd, C.J.; Smith, M.N.;

McAdam, K.P.W.J.; Raynes, J.G 149

Immunoglobulin E Response to Pertussis Toxin in Whooping Cough and after Immunization

with a Whole-Cell and an Acellular Pertussis Vaccine

Hedenskog, S.; Björkstén, B.; Blennow, M.; Granström, G.;

Granström, M 156

Disposition and Immunogenicity of Penicillin in the Rabbit

Christie, G.; Park, B.K 162

Natural Killer Susceptibility of Brain Tumor Cell Lines In

versely Correlates with the Degree of Cell Differentiation

and Not with the Level of Human Histocompatibility Anti

gen Expression

Alonso, C; Serrano, R.; Solana, R.; Peña, J 169

Spontaneous Regression in Murine Hypersensitivity Pneu-monitis: Lack of Immunological

Tolerance Takizawa, H.; Suko, M.; Kobayashi, N.; Ohta, K.; Shoji, S.; Horiuchi, T.; Okudaira, H.; Miyamoto, T.; Shiga, J. ... 173

Characteristic Nucleolar-Reticular Immunofluorescence Staining Pattern on Touch Prints of

Hamster Liver: A Marker for Scl-70 Antibody

Kühn, G.; Jarzabek-Chorzelska, M.; Kolacinska-Strasz, Z.;

Blaszczyk, M.; Chorzelski, T.P.; Jablonska, S

Unusual Precipitins in Pathological Human Sera

Kim, D.S.; Anthone, R.; Anthone, S.; Milgrom, F 188

IgG Rheumatoid Factor in Human and Rabbit Transplantation Sera Miyata, M.; Albini, B.;

Kreis, H.; Milgrom, F.; Dausset, J. 191

Detection and Characterization of IgE-Producing Cells in Patients with Clonorchiasis

Yanagihara, Y.; Kiniwa, M.; Kajiwara, K.; Joh, K.; Koba

yashi, A.; Watanabe, N 197

Dendritic Cell Accumulation in Draining Lymph Nodes dur

ing the Induction Phase of Contact Allergy in Mice

Kinnaird, A.; Peters, S.W.; Foster, J.R.; Kimber, 1202 
Abrogation of Spleen Macrophage Suppressive Activity by 15-

Deoxyspergualin

Yamamura, T.; Tabira, T 211

Effect of Magnesium Deficiency on Interleukin Production by

Fisher Rats: Effect of Interleukins on Reduced in vitro

Lymphocyte Responses to Concanavalin A and Lipopoly-

saccharide

Yiangou, M.; Hadjipetrou-Kourounakis, L 217

In vitro Reactivities of Blood Lymphocytes from Symptomatic

and Asymptomatic Pigeon Breeders to Antigen and Mitogens

Bouic, P.J.; Nel, N.C.; de Beer, P.M.; Joubert, J.R 222

Histamine-Releasing Activity of Endogenous Peptides on

Mast Cells Derived from Different Sites and Species

Arock, M.; Devillier, P.; Luffau, G.; Guillosson, J.J.; Re-

noux, M 229

Decreased Releasability of Basophils from Patients with Cold

Urticaria after Cold Exposure

Hessler, H.-J.; Pufahl, C; Christophers, E 236

Protection against Experimental Allergic Encephalomyelitis

with Complete Freund's Adjuvant Is Unaffected by Prosta-

glandin Synthesis Inhibition

Weber, F.; Hempel, K242

Gliadin Antibody Production by Small Intestinal Lymphocytes from Patients with Coeliac

Disease Ciclitira, P.J.; Hooper, L.B.; Ellis, H.J.; Freedman, A.R. . 246

Modulation of Human Peripheral Blood Eosinophil Function

by Tumor Necrosis Factor-Alpha

Whitcomb, E.A.; Wesolek, J.H.; Pincus, S.H250

IgE-Positive Cells in Human Intestinal Mucosa Are Mainly

Mast Cells (With 1 color plate)

Rognum, T.O.; Brandtzaeg, P256

Antibody Specificity in the Immune Response to Insulin

Mirza, I.H.; Wilkin, T.J 261

Immunoglobulin Synthesis and Gene Rearrangement in Atax-

ia-Telangiectasia B-Lymphoblastoid Cell Lines

Kumar, S.; Seymour, G.J.; Lavin, M.F 264

Responses of Antigen-Specific Long-Term Murine T Cell Lines to Wheat Gliadin Fractions

Howdle, P.D.; Hanson, D.G.; Trejdosiewicz, L.K.; Cicli

tira, P.J.; Smart, C.J.; Walker, W.A 269

Lipopolysaccharide-Reactive B Cells against Bromelain-

Treated Mouse Erythrocytes: Preferential Migration to and

Survival in the Peritoneal Cavity

Kawaguchi, S 275

Characterization of Grass Pollen-Specific IgE, IgA, IgM

Classes and IgG Subclasses in Allergic Patients

Desvaux, F.X.; Peltre, G.; David, B 281 
Reactivity of Autoantibodies in Systemic Lupus erythematosus with Synthetic Core Histone Peptides Muller, S.; Bonnier, D.; Thiry, M.; Van Regenmortel, M.H.V. 288

In vitro Sensitivity of Immature Human Mast Cells to Chemo-

therapeutic Agents

Butterfield, J.H.; Weiler, D.A 297

Prolonged Exposure of Neutrophils to Saline or Bronchoalveo-larLavage Fluid Does Not Alter Superoxide Anion Generation

Nguyen, P.; Shusterman, R.D.; Barnett, R.B.; Ishihara, Y.; Gottlieb, J.E.; Albertine, K.H.; Gee, M.H.; Peters, S.P. . 301

Pharmacological Effect of KC-404 on Leukotriene Release

from Human Leukocytes Induced by Ionophore A23187

Ohtsu, H.; Fujimoto, Y.; Yamauchi, K.; Tamura, G.; Taki-

shima, $\mathrm{T}$ 306

Short Communications

Monitoring of Active Groups of Cyanogen-Bromide-Activated

Paper Discs Used as Allergosorbent

Jaggi, K.S.; Gangal, S.V 311 